\title{
Vendor variety and market sales: A case study of the Williamsburg Farmers Market
}

\author{
Steven J. Archambault a* \\ Cal-Poly Pomona University \\ Shawn Trivette ${ }^{b}$ \\ University of Tennessee-Chattanooga
}

\author{
Phillip Warsaw ${ }^{\mathrm{c}}$ \\ Michigan State University
}

Alfonso Morales ${ }^{\mathrm{d}}$

University of Wisconsin

Submitted March 14, 2019 / Revised July 2 and August 30, 2019 / Accepted August 30, 2019 /

Published online February 27, 2020

Citation: Archambault, S. J., Trivette, S., Warsaw, P., \& Morales, A. (2020). Vendor variety and market

sales: A case study of the Williamsburg Farmers Market. Journal of Agriculture, Food Systems, and Community

Development, 9(2), 221-237. https://doi.org/10.5304/jafscd.2020.092.012

Copyright (C) 2020 by the Authors. Published by the Lyson Center for Civic Agriculture and Food Systems. Open access under CC-BY license.

\begin{abstract}
Although sales at farmers markets have been on the rise for a few decades, a regular challenge faced

a* Corresponding author: Steven J. Archambault, Assistant Professor, Department of Agribusiness \& Food Industry Management-Agricultural Science, Cal-Poly Pomona University; 3801 West Temple Avenue; Pomona, CA 91768 USA; +1-909-869-2190; sarchambault@cpp.edu; Linkedin: https://www.linkedin.com/in/steven-archambault-phd

b Shawn Trivette, Ph.D., Assistant Professor of Sociology, Department of Social, Cultural, and Justice Studies, University of Tennessee-Chattanooga; 615 McCallie Avenue; Chattanooga, TN 37403 USA; shawn-trivette@utc.edu

c Phillip Warsaw, Assistant Professor, Department of Community Sustainability, Michigan State University; 480 Wilson Road; East Lansing, MI 48824 USA; Linkedin: https://www.linkedin.com/in/phillip-warsaw/; warsawph@msu.edu

d Alfonso Morales, Ph.D., Professor, Department of Planning and Landscape Architecture and State Extension Specialist-

Food Systems and Marketplaces, University of Wisconsin; 925 Bascom Mall; Madison, WI 53706 USA; morales1@,wisc.edu; https://dpla.wisc.edu/staff/alfonso-morales/. Project websites: https://openair.org; and https://www.facebook.com/OpenAirMarketNetwork
\end{abstract}

by market managers is how to ensure that their vendors are best positioned to maximize what they can capture in market sales. Farmers markets have varying degrees of data collection and data analysis. This study aims to demonstrate the value of understanding data, so that market managers can take informed, effective steps to increase sales for their vendors. This is accomplished using 13 years of weekly sales data from the Williamsburg Farmers Market (WFM). The dataset categorized sales by produce, specialty crops, animal products, value-

\section{Authors' Note}

A version of the study results were presented at the Agriculture, Food, and Human Values Society meeting in June 2018 with the title Vendor Variety and Farmer Market Sales: Williamsburg, VA Case Study.

\section{Funding Disclosure}

We would like to acknowledge the U.S. Department of Agriculture Agriculture and Food Research Initiative (USDA AFRI) 2014-68006-21857 Indicators for Impact (principal investigator: Alfonso Morales) for funding this work.

\section{Data Statement}

Data can be shared with the permission of the Williamsburg Farmers Market Manager. 
added products, non-edible crafts, and plant sales. This allowed us to explore the relationship between vendor variety and sales. In this paper we ask: To what extent does vendor and product variety affect sales at farmers markets? We use dynamic panel econometric models, including a vendor variety index and other salient market factors, to explore how market characteristics may affect overall market sales. We find that greater vendor variety in terms of the products they offer increases sales both on the aggregate and across vendor types. Based on these findings we argue that one significant thing that market managers can do to boost sales for their vendors is to increase the variety of offerings through the recruitment of vendors who can bring differing product types to the market.

\section{Keywords}

Farmers Markets, Local Food, Vendor Variety, Econometrics, Time Series, Williamsburg Farmers Market

\section{Introduction}

Food sold in outdoor marketplaces has a long history of addressing food insecurity, unemployment, and the integration of new immigrant communities (Morales, 2000). While in decline in the mid-20th century, the number of farmers markets in the United States has since grown from 1,755 markets in 1994 to 8,761 in 2019, an increase of nearly 400\% (U.S. Department of Agriculture, Agricultural Marketing Service [USDA AMS], n.d.). This consistent rise in popularity is likely a validation of the multitude of ways in which farmers markets benefit local communities. These benefits fall into four primary categories: public health, economic well-being, social engagement, and ecological concerns (Morales, 2011; Olson, 2019; Schmit, Jablonski, \& Mansury, 2016).

However, a recent national survey of farmers market managers indicated that at least one-third of farmers markets were not seeing the same kind of growth in customer traffic and sales that others were experiencing (USDA National Agricultural Statistics Service [USDA NASS], 2016). Farmers markets face competition from other channels for the sales of local foods, including community supported agriculture (CSA) programs, grocery stores, and restaurants offering local ingredients in their dishes (Low et al., 2015; Printezis \& Grebitus, 2018). Thus, scholars and market participants alike are interested in understanding what factors increase overall competitiveness in a dynamic market for local food (Connell \& Hergesheimer, 2014). This information can provide farmer market managers with insight into the steps they can take to maintain and grow a strong customer base and help market vendors maximize their sales.

This context motivates our case study of the Williamsburg Farmers Market (WFM) in southeastern Virginia, which has kept extensive and detailed sales records since its inception. We examine more than a decade of sales data from this market with an eye toward both external (uncontrollable) and internal (controllable) factors that may increase or decrease sales. Sales data were broken down by general vendor type (i.e., vendors selling produce, or animal products, or value-added products, etc.). The data allowed us to explore the question: To what extent does vendor and product variety affect sales at farmers markets? While external factors such as weather, seasonality, and broader macroeconomic forces matter, we find from the data that greater product variety plays a significant role in increasing sales both on the aggregate and across vendor types. It is based on this evidence that we recommend to market managers looking to boost sales for their vendors that they recruit a pool of vendors with diverse product offerings. In addition, one of the primary contributions of our study is to illustrate how data can be used to better understand those factors that promote and inhibit farmers market sales.

We begin this paper with a brief outline of some of the literature on factors that have previously been identified as influencing sales at markets. We then describe the longitudinal dataset used for this study and provide an overview of the variables utilized, giving special attention to how we create a vendor variety index. We use time series regression analyses of overall market sales to examine the ways in which these various factorsespecially vendor variety_affect market sales. We conclude by offering possible explanations for some of the associations we find. 


\section{Literature Review}

Previous studies have considered the many challenges farmers markets face to stay open and remain relevant to the communities they serve. Stephenson, Lev, and Brewer (2008) discussed that the reasons markets struggle or fail is due to too few vendors, minimal product offerings, lack of administrative funds, management turnover, and insufficient compensation for market managers. Additional challenges faced by farmers markets include poor accessibility for many consumers, high prices of products, inconsistent availability of these products, too few farmers willing to participate, competition from conventional food sources, and unpredictable weather (Wittman, Beckie, \& Hergesheimer, 2012). The willingness of customers to pay a premium for local food sources has been investigated (Thilmany, Bond, \& Bond, 2008), but Printezis \& Grebitus (2018) pointed out that consumers are less reliant on farmers markets for local food since it is now more available in grocery stores and other locations.

Farmers markets are still an important part of the food landscape for a variety of reasons. However, it is necessary to understand the unique needs and desires of communities and consumers in order to more successfully attract them to the farmers market (Figueroa-Rodríguez, ÁlvarezÁvila, Hernández Castillo, Schwentesius Rindermann, \& Figueroa-Sandoval, 2019). Farmers market consumers are highly influenced by their ability to realize a high value for the products they buy, particularly if they are higher priced (Landis, Smith, Lairson, Mckay, Nelson, \& O’Briant, 2010; McGuirt et al., 2014).

Consumers are searching for other intangible experiences at farmers markets, which include interacting directly with farmers (Printezis \& Grebitus, 2018). There are a number of studies that discuss leisure and recreation as a primary motivation for attending farmers markets (Abelló, Palma, Waller, \& Anderson, 2014; Farmer, Chancellor, Gooding, Shubowitz, \& Bryant, 2011; Farmer, Chancellor, Robinson, West, \& Weddell, 2014). Specifically, customers are motivated by a varying and complex set of factors, which include access to fresh and healthy food, an interest in supporting local agriculture, social appeal, convenience, location, atmosphere, and prices (Byker, Shanks, Misyak, \& Serrano, 2012; Detre, Mark, \& Clark, 2010; Dodds et al., 2014). Similarly, Buman, Bertmann, Hekler, Winter, Sheats, King, and Wharton (2015) surveyed farmers market shoppers and found that freshness and abundance of produce, product presentation, social interactions, and attractions (live music and prepared food) were important attributes that enhanced the experience for farmers market shoppers; price and convenience were found to be of lesser concern for the majority of shoppers. Conner, Colasanti, Ross, and Smalley (2010) found that the freshness and abundance of produce, product presentation, social interactions, and attractions (live music and prepared food) are the most important attributes that enhance the experience for farmers market shoppers, perhaps even more than concern over price and convenience.

\section{Vendor Variety}

Several studies have specifically discussed the customer preference for product variety at farmers markets (Betz \& Farmer, 2016; Tey, Arsil, Brindal, Teoh, \& Lim, 2017). Hinrichs, Gillespie, and Feenstra (2004) discovered an increase in sales for farmers market vendors who added product types, including value-added and non-edible products. Mack and Tong (2015) found that customers were willing to travel to farmers markets outside their area if the location was open during convenient hours, had memorable marketing, provided an enjoyable social atmosphere, and had good quality and variety of products.

Beyond just farmers markets, consumers have demonstrated across market types that they prefer shopping experiences that provide them with product variety. The marketing literature that describes a positive relationship between variety in product offerings and revenue is well-established (Baumol \& Ide, 1956; Kahn \& Lehmann, 1991). Briesch, Chintagunta, and Fox (2009) noted that product assortment was even more important than retail price when consumers were determining where to shop. Tan and Cadeaux (2011) observed that an increased variety of brands within a product type increase sales throughout that product type.

Farmers markets by their nature are a diversi- 
fied institution in which consumers buy goods they may otherwise purchase at grocery stores, online, or other venues. We are not aware of any studies that attempt to quantify the contribution of variety toward farmers market sales, as the present analysis does. We are also unaware of any studies that have carried out a time series analysis of an individual market's sales. This is not to say there are not econometric analyses of a smaller collection of data points, some across multiple markets. For example, Printezis and Grebitus (2018) analyzed the average sales of markets across Iowa, controlling for population, education level, proximity to markets, household income, and population. Freedman et al. (2017) considered the patterns of SNAP purchases at various farmers markets in Cleveland, Ohio. Roubal and Morales (2016) mapped farmers markets against poverty and race in Chicago. Our research is novel in its attempt to quantify the factors promoting and inhibiting sales, with a particular focus being on one market over an extended period of time.

\section{Methods and Data}

In this section we describe the case under consideration and the data available from it. We describe how we use the available data and a few external sources to operationalize our variables. In particular, we explain how we developed the variety index. We then briefly describe our analytic strategy.

\section{The Case: Williamsburg Farmers Market}

The Williamsburg Farmers Market ${ }^{1}$ (WFM) is a longstanding and prominent market based in Williamsburg, Virginia, which supports direct agricultural commerce. Since opening in 2002, the market manager has collected basic sales reports from every vendor, as well as customer and vendor counts at every Saturday market. Specifically, this includes how many vendors were in attendance, the general product type of the vendor (given further explanation below), the dollar-value sales of every vendor, how many customers turned out, and notes of special events occurring at the market or in the surrounding area that day. It should be noted that the decision of which data were to be collected was made by the market organizers. The data collected did not include surveys of customers, the amount of Supplemental Nutritional Assessment Program credit being spent, or many other potential data elements.

The market ran initially from the start of May through the end of October, with special holiday openings in mid-November and mid-December. In 2007 the market began to open for other holidaythemed days in the spring, specifically once per month in February, March, and April. In 2011 it shifted its full-season opening date to the first weekend of April and has since held this window consistently. Our dataset spans 2002-2014 and contains 399 sets of observations (for each week the market was open). On average, there are 32 market days each year.

\section{Operationalization of V ariables}

Our primary dependent variable is market sales, adjusted to 2010 U.S. dollars to account for inflation. As the dataset contains individual sales data for each vendor by week of the market, we were able to create the Aggregate Sales variable by summing all vendor sales in a given week.

One of our primary independent variables of interest is the Variety Index. We developed this index by first categorizing all market vendors into one of six general types (see Table 1). ${ }^{2}$ Those six non-overlapping types include Produce (those offering a general mix of common crops), Specialty Items (those that specialize in a specific product, such as berries, orchard fruits, peanuts, asparagus, lavender, or honey), Livestock (those that specialize in meat, dairy, or eggs, and occasionally seafood products), Value-added Products (e.g., baked goods, cheese [produced from off-site milk], popsicles, canned goods, etc.), Plants (flow-

\footnotetext{
${ }^{1}$ https://williamsburgfarmersmarket.com/

${ }^{2}$ In most cases, the data categorized vendor by the general category of items sold. The data did not indicate exactly which items individual vendors were selling. For example, a vendor selling produce may have been selling microgreens, but also may have been selling sweet corn. The analysis only considers more general vendor categories. If a vendor sold more than one item type (like produce and a value-added product), they were categorized by what their greatest emphasis was.
} 


\section{Table 1. Comparisons by Vendor Types}

\begin{tabular}{lccc}
\hline & $\begin{array}{c}\text { Average Number } \\
\text { in 2014 }\end{array}$ & $\begin{array}{c}\text { Average Ratio weekly sales } \\
\text { at market (\%) }\end{array}$ & $\begin{array}{c}\text { per vendor in 2014 } \\
\text { (US\$, 2010) }\end{array}$ \\
\hline Pendor Types & 7 & $14-17 \%$ & $\$ 888.27$ \\
Specialty item vendors & 9 & $16 \%$ & $\$ 982.32$ \\
Livestock-related product vendors & 7 & $16 \%$ & $\$ 710.92$ \\
Value-added item vendors & 17 & $40 \%$ & $\$ 788.56$ \\
Vendors specializing in plants typically for & 8 & $12-13 \%$ & $\$ 720.97$ \\
gardening/decoration & & $13 \%$ & $\$ 361.39$ \\
Non-edible item vendors & 9 & & \\
\hline
\end{tabular}

ers, perennials, bulbs, and other items not usually meant for human consumption), and Non-edibles (e.g., Christmas decorations, lawn and household ornaments, worm castings, perfume, knife sharpening, and soap). Many vendors in the non-edible category are only present at early spring and winterholiday markets and/or appear with less frequency in the summer and early fall markets.

Our analysis required tracking the variety of vendors present at each weekly market. The aim was to understand if one vendor type (such as Produce) dominates the market on any given market day. To do this, we used the categorization schema and the records of which vendors were present at the market each week to create a sum of shares Variety Index, as follows:

$$
I N D E X=1 / \sum_{i}^{N=6}\left(\frac{\# \text { of Vendor Type }}{\#}\right)^{2}
$$

This index is similar to the Herfindahl Index (HI), which measures concentration in a given industry by summing up the squares of the market share that firms in an industry have (see, for instance, Rhoades, 1993). With the HI, higher values indicate higher levels of concentration and, correspondingly, lower levels of competition. Here, we are summing up the squared shares (or percentage) of total vendors that each vendor type represents. However, for ease of interpretation, we take the reciprocal of this summation so that markets that are less diverse will have a smaller value. For this reason, we also scale the term up by multiplying by 100.

To illustrate this concept, consider a market with 20 vendors, 15 of which are produce vendors, and 5 are value-added vendors. For this market, the INDEX would be $=100 /\left[(15 / 20)^{\wedge} 2+(5 / 20)^{\wedge} 2\right]$ $=106$. If, however, at the same market there were ten of each type of vendor, we would have $\operatorname{INDEX}=100 /\left[(10 / 20)^{\wedge} 2+(10 / 20)^{\wedge} 2\right]=200$. Here, the market with an even split between vendor types has a higher INDEX value than the market with a heavier concentration of produce vendors.

Some markets also run occasional special events, either on their own or in conjunction with happenings in the surrounding area, and the WFM is no exception. The Event variable is a count of the number of special events occurring at or near the market. While we have information on special events at the WFM, one significant limitation is that the information is not complete in the database. Records indicate special events in the spring and summer months (March through August), but not for other times of the year. We further discuss how we handle this limitation in the Analytic Strategy section, below.

There is also a variety of factors that are outside of a market's control but still important to account for when trying to predict sales. As in agriculture generally, market attendance and sales are both seasonal and weather-dependent. Seasonality is assessed using a set of dummy variables for each season (Winter: Dec-Feb, Spring: Mar-May, Summer: June-Aug, and Fall: Sept-Nov) as well as a dummy variable for the annual Christmas Market.

We account for weather using two dimensions, both taken from the weather station at Newport News/Williamsburg International Airport, which, while not precisely at the market, accurately repre- 
sents weather conditions in the area. ${ }^{3}$ The airport is approximately 18 miles $(29 \mathrm{~km})$ from the market's location. The weather station provided us with rainfall measurements for each week (in $\mathrm{mm}$ ) since the opening of the market. It also provided the recorded high temperature and the historic average high temperature for that day each year. These were combined to make a ratio of the daily high compared to the average high (temperature). This study also includes a second temperature term, which measured the summertime temperature ratio, as warm days in the summer may be a drag on sales specifically in the summer compared to warm days at other times of the year.

As a simple assessment of macroeconomic conditions, we also include the monthly unemployment rate for the city of Williamsburg for each week the market was open. We use Unemployment as a crude measure of general economic conditions on the assumption that if many people are out of work, they may limit their spending at places like farmers markets. ${ }^{4}$

Market sales are a direct function of customers spending money. As such, what we are really trying to explain is what factors will drive customers to both attend the market and to purchase things. Figure 1 indicates how these factors are related, with all the variables listed above linking through customer counts, ultimately to explain market sales. The dataset has customer counts for just under half the weeks the market is open; customer count data are available for the spring and summer, but not for the fall and winter (suggesting a systematic error in their recording). We discuss how we show the relationship between customer turnout and the other variables under study in the Analytic Strategy section, but the primary analyses link the independent variables outlined above directly to market sales, on the assumption that customer activity is the "invisible" mechanism linking them.

\section{Analytic Strategy}

The first step in analyzing our data was to visualize the two-way relationships between key explanatory variables and aggregate market sales. The two-way correlation provides an indication of the relationship between sales and key factors in the data set. However, multivariable regression analysis enables us to analyze the effect of various factors simultaneously. The econometric methodology is laid out in this section.

Since most of the continuous variables (everything except seasonality) are not normally distributed, we took the natural log of each before creating our models. This means the coefficients can be interpreted as elasticity, where a percentage change in the explanatory variable results in a percentage

\section{Figure 1. Conceptual Diagram of the Internal and External Factors Influencing Farmers Market Customer Traffic and Resulting Sales}

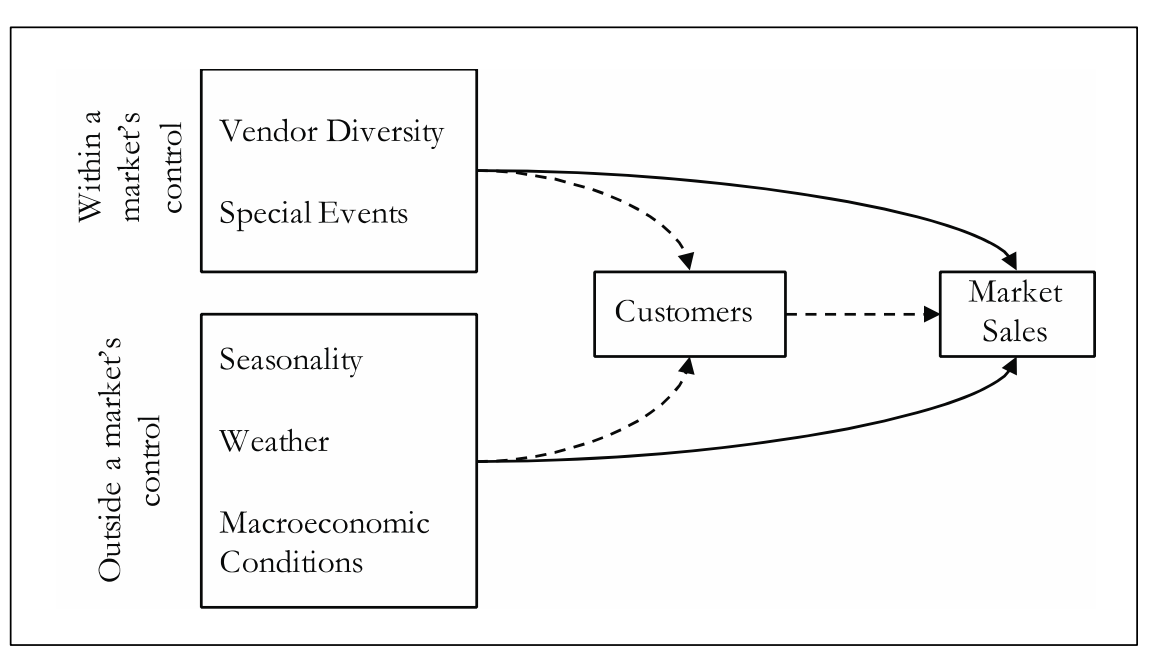

\footnotetext{
${ }^{3}$ The market manager also tracked average temperature and a simple yes/no indicator of whether or not it rained on a given market day. We use the airport's weather station data for greater precision, but it is worth noting that the datasets are in close alignment. Also, shoppers traveling to the market from outside the immediate area would also be influenced by regional weather.

${ }^{4}$ Incorporating government food benefit programs (such as SNAP-EBT or WIC FMNP) might be another way to approach this, as they also form a general economic indicator. However, we do not know how many such benefits are used at the market, and shifts in such benefits come after there is already an economic downturn, making it a lagging indicator.
} 
change in the dependent variable that is equivalent to the coefficient. Dummy variable coefficients are interpreted similarly, but, changing to 1 from 0 , or 0 to 1 , is considered a $100 \%$ change, so coefficients are multiplied by 100 to know the effect of a change in the dummy variable on the dependent variable. Similarly, to account for trends occurring over time, we include a set of dummy variables for each year from 2002 to 2013 (excluding 2014).

We use three regression approaches to understand the relationships between our variables. We start with a standard OLS multivariate regression model. Because we are using time-series data, we then build an Autoregressive Moving Average with Exogenous Inputs (ARMAX) regression model, which provides a flexible framework to consider the impact of time effects on the independence of the error term (Shumway \& Stoffer, 2011) (see the Methodological Appendix). In both models, our dependent variable is the log of Aggregate Sales. We use all independent variables listed above except for Events and Customer Counts, largely because both are incomplete in the dataset and reduce our sample size by over half. Additionally, while it is almost certainly the case that additional customers increase sales, without dealing with this term's endogeneity, our estimates (both for the

\section{Figure 2. Aggregate Weekly Sales Data at the Williamsburg Farmers Market, 2002-2014 (Adjusted for Inflation in 2010 US\$)}

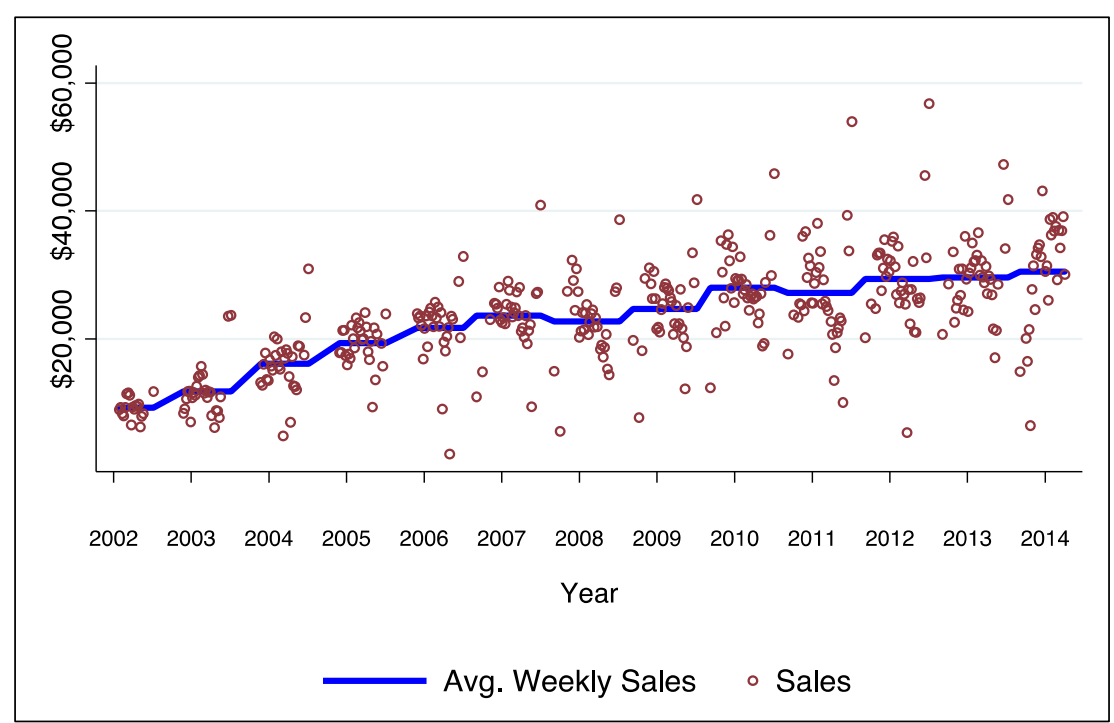

coefficients for Customer Counts and any co-predicting factors) will be biased.

To further explore (and verify) the role of customers in this overall process of generating market sales, we also create a model using Three Stage Least Square (3SLS). This method is used to estimate a system of structural equations, ${ }^{5}$ where the endogenous explanatory variables appear as dependent variables in other equations within the system (Zellner \& Theil, 1962). Here, we seek to jointly estimate predictive equations for Aggregate Sales and Customer Counts, where Customer Counts appear as an independent variable predicting Aggregate Sales. Many of the same explanatory terms are in both model components in the 3SLS model. However, the Customer Count equation also includes a Lagged Aggregate Sales term to account for potential autocorrelation and includes the count of Special Events that occurred on the market day (as such data were only collected on the days that Customer Count data were collected). There are many fewer observations in this model due to fewer weeks when such data were reported.

\section{Results}

Across the 13-year period, market sales have averaged US $\$ 23,500$ per week. This translates to about US $\$ 785$ per vendor each week. However, these figures have not been consistent over time; total market sales have increased steadily across the years, as has the number of vendors. For example, in the first year of the market (2002), average weekly sales for the whole market were US\$9,200, but by 2014 this had increased to approximately US\$31,000, an increase of more than threefold. Figure 2 provides an illustration of the growth in sales through time. The plateau in sales growth in the last seven years of the data set is not dissimilar to trends in

\footnotetext{
${ }^{5}$ This is in contrast with the Two Stage Least Squares (2SLS) approach, used to estimate a single structural equation in two steps.
} 
Table 2. Descriptive Statistics

\begin{tabular}{|c|c|c|c|c|c|c|}
\hline Variable & Explanation & $\begin{array}{c}\text { \# of } \\
\text { Observations }\end{array}$ & Mean & Std. Dev. & Minimum & Maximum \\
\hline SALESA & Weekly sales for the market, in 2010 US $\$$ & 399 & $23,431.18$ & 8545.6 & 7.61 & 10.95 \\
\hline CUST & Number of customers at each market & 187 & $1,112.25$ & 311.353 & 142.0 & 2165.0 \\
\hline INDEX & Vendor type variety index & 399 & 4.423 & 0.4916 & 2.750 & 5.553 \\
\hline EVENT & Number of special events occurring at the market & 187 & 0.872 & 0.9917 & 0.00 & 5.000 \\
\hline UNEMP & $\begin{array}{l}\text { Monthly percentage of people in the county } \\
\text { unemployed }\end{array}$ & 399 & 7.996 & 2.3912 & 4.10 & 17.400 \\
\hline RAIN & $\begin{array}{l}\text { Measured daily precipitation at the Williamsburg- } \\
\text { Jamestown Airport, in } \mathrm{mm}\end{array}$ & 399 & 3.634 & 12.1443 & 0.00 & 134.6 \\
\hline TEMPR & $\begin{array}{l}\text { Ratio between the daily high temperature and } \\
\text { the average temperature for that day }\end{array}$ & 399 & 1.023 & 0.0968 & 0.695 & 1.299 \\
\hline TEMPRS & $\begin{array}{l}\text { Ratio between the daily high temperature and } \\
\text { the average temperature for that day, summer } \\
\text { days ( } 0 \text { for non-summer days) }\end{array}$ & 399 & 0.421 & 0.5032 & 0.00 & 1.195 \\
\hline WIN & $\begin{array}{l}\text { A dummy variable where } 1=\text { winter season (Dec., } \\
\text { Jan., Feb.), } 0=\text { not winter }\end{array}$ & 399 & 0.043 & 0.2022 & 0 & 1 \\
\hline SPR & $\begin{array}{l}\text { A dummy variable where } 1=\text { spring season (Mar., } \\
\text { Apr., May), } 0=\text { not spring }\end{array}$ & 399 & 0.228 & 0.4201 & 0 & 1 \\
\hline SUM & $\begin{array}{l}\text { A dummy variable where 1=summer season } \\
\text { (Jun., Jul., Aug.), } 0=\text { not summer }\end{array}$ & 399 & 0.414 & 0.4931 & 0 & 1 \\
\hline FALL & $\begin{array}{l}\text { A dummy variable where } 1=\text { fall season (Sept., } \\
\text { Oct., Nov.), } 0=\text { not fall }\end{array}$ & 399 & 0.308 & 0.4624 & 0 & 1 \\
\hline XMAS & $\begin{array}{l}\text { A dummy variable where } 1=\text { Christmas Market, } \\
0=\text { not Christmas }\end{array}$ & 399 & 0.183 & 0.3871 & 0 & 1 \\
\hline \multicolumn{7}{|c|}{ Vendor-level data } \\
\hline SALESV & Weekly sales per vendor, in 2010 US\$ & 11,862 & 788.15 & 595.479 & 1 & 7696.7 \\
\hline SPEC & $\begin{array}{l}\text { Dummy variable where } 1=\text { specialty vendor, } \\
0=\text { other vendor type }\end{array}$ & 11,862 & 0.122 & 0.3278 & 0 & 1 \\
\hline PROD & $\begin{array}{l}\text { Dummy variable where } 1=\text { produce vendor, } \\
0=\text { other vendor type }\end{array}$ & 11,862 & 0.184 & 0.3877 & 0 & 1 \\
\hline$V A L$ & $\begin{array}{l}\text { Dummy variable where } 1=\text { value-added vendor, } \\
0=\text { other vendor type }\end{array}$ & 11,862 & 0.330 & 0.4702 & 0 & 1 \\
\hline NONED & $\begin{array}{l}\text { Dummy variable where } 1=\text { non-edible food vendor, } \\
0=\text { other vendor type }\end{array}$ & 11,862 & 0.072 & 0.2582 & 0 & 1 \\
\hline MEAT & $\begin{array}{l}\text { Dummy variable where } 1=\text { meat vendor, } 0=\text { other } \\
\text { vendor type }\end{array}$ & 11,862 & 0.149 & 0.3558 & 0 & 1 \\
\hline PLANT & $\begin{array}{l}\text { Dummy variable where } 1=\text { plant vendor, } 0=\text { other } \\
\text { vendor type }\end{array}$ & 11,862 & 0.143 & 0.3497 & 0 & 1 \\
\hline
\end{tabular}

other direct-to-consumer market channels

(Printezis \& Grebitus, 2018), and highlights the need for markets to consider what they can do to keep themselves relevant and attractive to consumers. Further details on sales trends over time, including those broken down by vendor type, can be found in Trivette, Archambault, and Morales (2015).

Basic summary statistics can be found in Table
2. It rained on $35 \%$ of the days the market was open. Generally, the rainfall was less than $4 \mathrm{~mm}$, although in some cases it was recorded as over 25 $\mathrm{mm}$. In both summer and non-summer seasons, $25 \%$ of the daily recorded temperatures were below the historical averages. In approximately one-tenth of the market days, the recorded high temperature was $13 \%$ greater than the historical average. The Unemployment Rate ranged from 


\section{Figure 3. Two-way Graphs Illustrating Data Relationships between Key Explanatory Variables and Weekly Farmers Market Sales, in 2010 Dollars}

Each graph includes an estimated trend line to better illustrate the relationship.

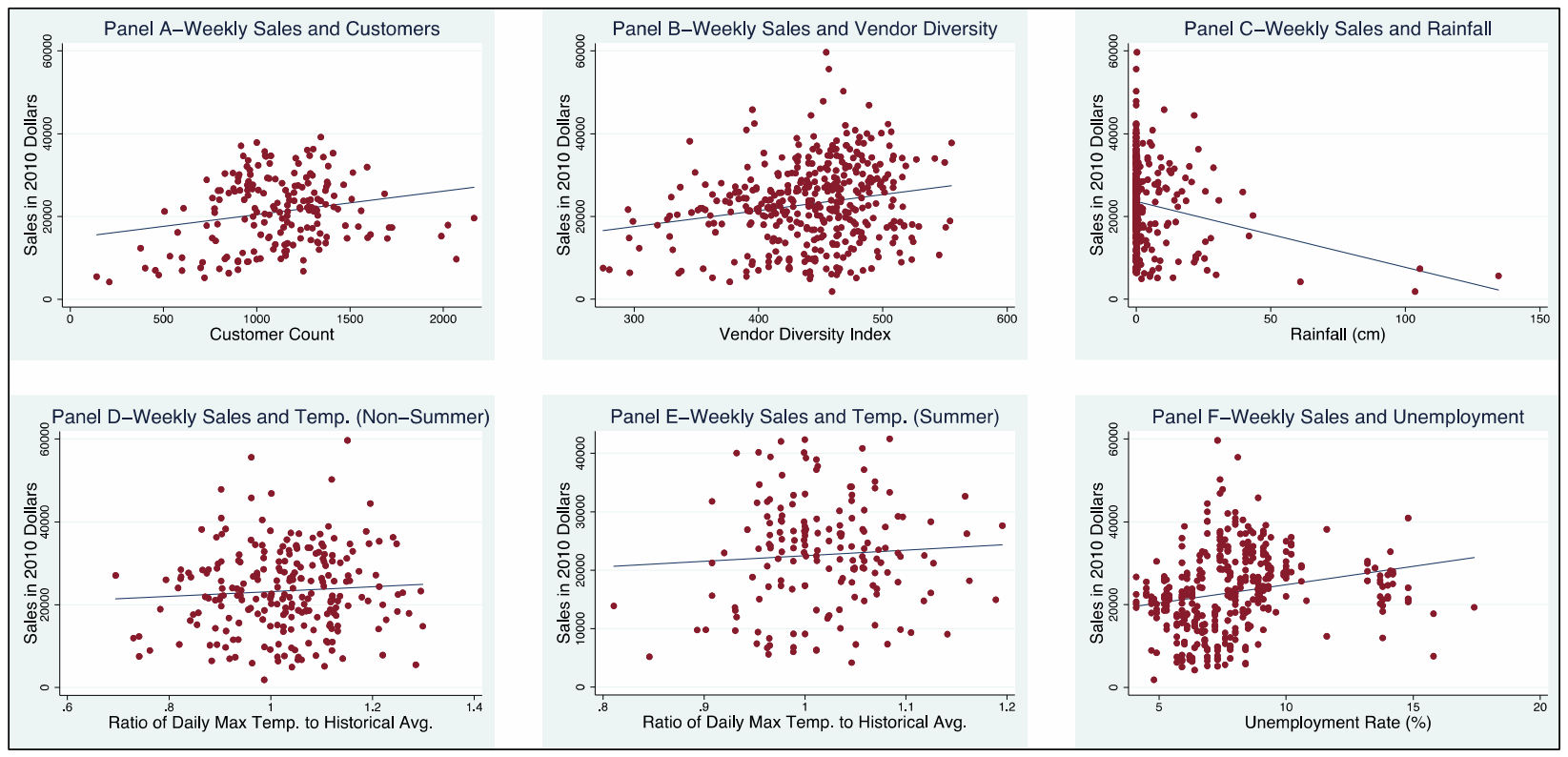

$4.1 \%$ to $17.4 \%$ during this period, with the major increases corresponding primarily to the 2008 financial crisis. This was generally on par with unemployment nationwide.

For the spring and summer months (the only periods in which Customer Counts and Events were recorded), there were typically several special events each month, with multiple events during many weeks in the months of July and August. The market typically saw just over 1,000 customers weekly, although as with the sales trends, this grew over the years and varied widely even within a given year. Of the recorded weeks, Customer Counts ranged from fewer than 150 in one week to over 2,000 in another week.

\section{Data Relationships}

Figure 3 displays scatter diagrams plotting weekly aggregate sales with many of the key explanatory variables included in the study. Also included in each graph is a fitted line using ordinary least squares. Panel A shows sales increasing with more customers, which is expected. Panel B illustrates increasing sales with increasing vendor variety, as expected. Panel C illustrates a decrease in sales as rainfall increases. Although the relationships appear weak, Panel D and E both show sales going up when the ratio of the daily maximum temperature to the historic average maximum temperature is higher. This is expected in the non-summer season and for the summer season may indicate that customers are not scared off by atypically warm days. Panel F shows a weak positive relationship between sales and the unemployment rate, suggesting there is more farmers market activity when the economy is not performing as well.

\section{Econometric Modeling}

The econometric results are somewhat more reliable than the relationships revealed in the two-way analysis, as we are controlling for multiple effects that simultaneously affect sales. The results of Models 1 and 2 are found in Table 3. The results show that higher unemployment rates have a depressing effect on sales, which is different from the two-way effect. It makes sense that higher unemployment would decrease sales, as buying food from local sources is generally a more expensive option than purchasing it from more conventional sources, such as grocery stores.

The presence of rain in the area also shows a negative relationship with farmers market sales, as 
expected. Somewhat contrary to our expectations, above-average temperatures in the summer give a slight boost to sales, suggesting that customers may not be dissuaded by unseasonably hot summer days. The weather is a constant concern for market managers and vendors, but the strongest association by far is the relationship between the Variety Index and Aggregate Sales. With the exception of one of the year dummy variables, the Variety Index coefficient has the greatest magnitude of any coefficient in the model. The direct interpretation of these numbers indicates that a percent change in vendor variety would result in a 0.724 $0.809 \%$ increase in overall sales. The simple takeaway is that more variety among the vendors at the market leads to more sales overall. Further, although other external factors do matter, the effect of vendor variety on market sales is greater than for any of the other components.

As noted previously, it is likely that the Customer Count term is endogenous with other variables included in the models. If so, including such a variable would likely mean the error term is correlated with other independent variables included, making them no longer independent. To account for this problem, Model 3 analyzes both Aggregate Sales and Customer Counts in the same model, using a three stage least squares approach (3SLS). Results for Model 3 are found in Table 4.

We can see from Model 3 that multiple variables have statistically significant relationships with Customer Counts. The Variety Index has a positive and significant relationship with Customer Counts, indicating that a one percent change in vendor variety increases customer counts by $0.416 \%$. As in the previous models, the presence of rain has a slight (but still significant) negative effect on customer turnout. The coefficient of Events shows a slight positive and significant effect on bringing people to the market, as does the Lag of Aggregate Sales. Other variables are not significant in relationship to customers. Durbin Watson and Harvey LM Tests indicate that there is no serial autocorrelation in Model 3.

The Customer Count coefficient is highly significant in its relationship with Aggregate Sales in Model 3. Many, although not all, of the same variables that were significant in Models 1 and 2 are also significantly associated with Aggregate Sales in Model 3. However, in this simultaneous model, these explanatory variables have two effects on Sales. First, there is a direct effect through the inclusion of the variable in the Sales equation. Second, there is the indirect effect through the Customer equation. For instance, the Variety Index is 
strongly significant in its direct relationship with Aggregate Sales in Model 3, but this term is also important in bringing more Customers to the market, represented by a highly statistically significant relationship in the Customer equation. This suggests that vendor variety not only attracts more customers, but also encourages more spending once those customers are present.

As another example of this dynamic relationship, consider the Unemployment term. This coefficient is significant in the Sales model, but not in the Customer model, suggesting that people who attend the market will do so regardless of broader

Table 4. Joint Estimation of Sales and Customers Using a Three-Stage Least Squares Simultaneous Regression Approach

\begin{tabular}{|c|c|c|c|c|}
\hline \multicolumn{5}{|l|}{ Model 3} \\
\hline \multirow[b]{2}{*}{ CONS } & \multicolumn{2}{|c|}{ In SALESA } & \multicolumn{2}{|c|}{ In CUSTOMERS } \\
\hline & $6.278 * * *$ & $(0.822)$ & -0.145 & $(1.730)$ \\
\hline In INDEX & $0.534 * * *$ & $(0.123)$ & $0.416 *$ & $(0.238)$ \\
\hline In UNEMP & $-0.549 * * *$ & $(0.184)$ & -0.382 & $(0.351)$ \\
\hline In RAIN & -0.00944 & $(0.0146)$ & $-0.0933 * * *$ & (0.0199) \\
\hline In TEMPR & 0.216 & $(0.200)$ & 0.340 & $(0.416)$ \\
\hline In TEMPRS & $0.110 * *$ & $(0.0433)$ & 0.0587 & $(0.0891)$ \\
\hline In CUST & $0.655 * * *$ & $(0.118)$ & & \\
\hline In EVENTS & & & $0.0996 * *$ & $(0.0425)$ \\
\hline In LAGSALESA & & & $0.0227 * * *$ & $(0.00652)$ \\
\hline$S P R$ & -0.0757 & $(0.0686)$ & $0.238 *$ & $(0.124)$ \\
\hline SUM & -0.0885 & $(0.0751)$ & $0.235 *$ & $(0.134)$ \\
\hline YR2002 & $-0.725 * * *$ & $(0.0702)$ & -0.00906 & $(0.147)$ \\
\hline YR2003 & $-0.583 * * *$ & $(0.0568)$ & 0.0461 & (0.119) \\
\hline YR2004 & $-0.497 * * *$ & (0.0569) & 0.152 & $(0.117)$ \\
\hline YR2005 & $-0.394 * * *$ & $(0.0606)$ & $0.227 *$ & (0.119) \\
\hline YR2006 & $-0.194 * * *$ & $(0.0634)$ & 0.124 & $(0.135)$ \\
\hline YR2007 & $-0.175 * * *$ & $(0.0667)$ & 0.179 & $(0.146)$ \\
\hline YR2008 & 0.0633 & $(0.0564)$ & $0.204 *$ & $(0.113)$ \\
\hline YR2009 & $0.447 * * *$ & $(0.135)$ & $0.441 *$ & $(0.244)$ \\
\hline YR2010 & $0.395 * * *$ & $(0.0828)$ & 0.207 & (0.159) \\
\hline YR2011 & $0.410 * * *$ & $(0.0637)$ & 0.0165 & $(0.133)$ \\
\hline YR2012 & $0.387 * * *$ & $(0.0694)$ & 0.0314 & $(0.145)$ \\
\hline YR2013 & $0.284 * * *$ & $(0.0639)$ & 0.0622 & $(0.134)$ \\
\hline$N$ & 187 & & 187 & \\
\hline $\mathrm{R}-\mathrm{Sq}$ & 0.909 & & 0.419 & \\
\hline
\end{tabular}

Robust Standard errors in parentheses, * $p<.1 * * p<.05 * * * p<.01$ economic conditions. However, when those conditions are tight, they may not be inclined to spend as much money as they would otherwise. Conversely, the presence of rain may keep people away (as seen in the significant coefficient on Rain in the Customer model), but if people show up, they are going to spend whatever they would have on any other day (as seen in the insignificance on Rain in the Sales model).

\section{Discussion and Conclusion}

Our models shed light on the relative influence of some of the more likely factors that influence mar-

ket sales. While weather and the wider economic situation matter and provide a context within which markets operate, this does not mean that markets cannot exert some form of agentic control to better position themselves within these contexts. One significant step that markets can take -which would greatly affect sales-is to increase product diversity. This is not a new concept for analysts of farmers markets (see Betz \& Farmer, 2016; Hinrichs et al., 2004; \& Tey et al., 2017), but it does provide quantitative evidence that a variety of vendor types is important. As our models indicate, greater variety of vendor types increases overall sales (and does so across all vendor types; separate analyses are available on request).

One possible explanation for this is that greater variety allows customers to more easily engage in "one stop" shopping. Being able to purchase a variety of goods at the same market 
space encourages consumers to spend more money overall for the added convenience (Mack \& Tong, 2015; McEachern, Warnaby, Carrigan, \& Szmigin, 2010). Customers may come to the market intending to purchase one type of good (such as fresh produce) and decide to expand their purchases to other items upon finding a wider array of available options. Although the exact mechanism is beyond the ability of our data to answer definitively (and is an important consideration for future research), what is clear is that increased variety of vendor types contributes to greater sales for all vendors.

Certainly, this points up the problem of product availability. Many market managers observe a relative absence of product diversity, which must be related in part to opportunities local people have to engage in food production. The opportunity to engage in production varies greatly by regulatory context (Meenar, Morales, \& Bonarek, 2017). However, let us turn for a moment to factors more clearly within the control of the market. We must remember that Williamsburg, Virginia, is both a college town (the College of William and Mary) as well as a city of historic interest (Colonial Williamsburg, Historic Jamestowne). While the market enjoys educated consumers, like most tourist destinations the community as a whole also has substantial economic inequality and food insecurity. With this heterogenous customer base, there is likely a demand for a diverse array of products. Increasing product diversity is, in part, about bringing in more vendors, but it is also about making sure that those additional vendors are not duplicating (excessively) the products that are already available. It would also be useful to track how the individual product variety within each category (for example, the variety of vegetable types within the produce category) affects sales. This level of detail was not available in this study, but a reasonable hypothesis is that improved variety within categories would positively affect sales at the market. Further, data collection of this type is now possible with tools such as Farm2Facts (discussed below).

Another characteristic that management can control is the number and type of special events. Such events would increase market popularity in a college town and so diversify attendance at the market across customer segments. They are another way to boost sales, adding to the intangible experiences customers are seeking (Buman et al., 2015; Dodds et al. 2014). However, it is important to recognize that not all vendors will experience this boost in the same way, and some may be negatively affected by it. The nuances of such associations and the reasons for them are pertinent questions that managers can answer; we hope that future research endeavors will provide further insight here (again, Farm2Facts would be a useful tool in this area).

Finally, another contextual feature in control of the market is data collection. We want to make clear that the findings we have shown would not have been possible were it not for the consistent data collection efforts by the manager of the market under study. Market management at WFM is committed to a market that serves every subpopulation. The collecting of farmers market data is considered very important by researchers and market practitioners, and many farmers markets have some form of data collection (Karpyn, Kim, DaCosta, Gasinu, \& Law, 2012). However, consistent data collected over the long term is absent in most markets, making WFM an exception that demonstrates the need for further engagement. The challenge, of course, is that data collection often falls at the feet of market management, typically volunteers who are not paid and have little to no training in sound data collection techniques (Morales, 2019). Even when paid, they often are too busy to act on opportunities to identify and achieve the goals associated with those data collection benefits. This is an arena in which academics and other supporting organizations have collaborated to produce data collection toolkits that are useful to managers, that further professionalize their work and make them citizen scientists in a relatively inexpensive way. The longitudinal, panel data collection that Farm2Facts is producing will support individual market managers and market organizations, and shed light on local, state, and federal policy questions of interest to the sector.

There are many opportunities to use data from farmers markets to ask specific questions of interest at a market. It is important that data-collection activities match the particular needs of the market, 
based on the unique community settings (Wilson, Witzling, Shaw, \& Morales, 2018; Witzling, Shaw, Wilson, \& Morales, 2019). Market managers influence each other in this regard (Quintana \& Morales, 2015). One area of interest is the success of farmers markets as an accessible source of fresh and healthy food for underserved communities, particularly those where a high density of supplemental SNAP recipients reside (Mino, Chung, \& Montri, 2018; Roubal, Morales, Timberlake \& Martinez-Donate 2016). This multivariate data analysis approach can be useful, particularly if data on SNAP utilization is collected weekly by farmers market managers. Karakus, Milfort, MacAllum, and Hongsheng (2014) found that SNAP recipients found better variety and higher-quality produce at farmers markets than they did at other retail locations (see also Parsons \& Morales, 2013). Future research could track the diversity of products with more detail than considered in this paper and might also track the price of products. One datacollection tool to assist farmers markets is Farm2Facts, ${ }^{6}$ a tool designed by researchers and practitioners. Farm2Facts suggests collecting metrics in the categories of economic (e.g., visitors and sales data for each market), social (e.g., number of visitors from a specific zip code), and ecological factors (e.g., average distance the food traveled to the market) —all of which can be used to ask questions of interest to market stakeholders. In short, farmers markets can serve as tools of community development (Morales, 2009; Morales, Balkin, \& Persky, 1995), and this study has shown the important contribution they make to a local economy.

\section{Acknowledgments}

We would like to acknowledge Tracy Herner, market manager of the Williamsburg Farmers Market, for providing access to the market data.

\section{References}

Abelló, F. J., Palma, M. A., Waller, M. L., \& Anderson, D. P. (2014). Evaluating the factors influencing the number of visits to farmers' markets. Journal of Food Products Marketing, 20(1), 17-35. https://doi.org/10.1080/10454446.2013.807406

Baumol, W. J., \& Ide, E. A. (1956). Variety in retailing. Management Science, 3(1), 93-101. https://doi.org/10.1287/mnsc.3.1.93

Betz, M. E., \& Farmer, J. R. (2016). Farmers' market governance and its role on consumer motives and outcomes. Local Environment, 21(11), 1420-1434. https://doi.org/10.1080/13549839.2015.1129606

Briesch, R. A., Chintagunta, P. K., \& Fox, E. J. (2009). How does assortment affect grocery store choice? Journal of Marketing Research, 46(2), 176-189. https://doi.org/10.1509/imkr.46.2.176

Buman, M. P., Bertmann, F., Hekler, E. B., Winter, S. J., Sheats, J. L., King, A. C., \& Wharton, C. M. (2015). A qualitative study of shopper experiences at an urban farmers' market using the Stanford Healthy Neighborhood Discovery Tool. Public Health Nutrition, 18(6), 994-1000. https://doi.org/10.1017/S136898001400127X

Byker, C., Shanks, J., Misyak, S., \& Serrano, E. (2012). Characterizing farmers' market shoppers: A literature review. Journal of Hunger \& Environmental Nutrition, 7(1), 38-52. https://doi.org/10.1080/19320248.2012.650074

Connell, D. J., \& Hergesheimer, C. (2014). Strengthening the core business of farmers markets through strategic business planning. Journal of Agriculture, Food Systems, and Community Development, 4(4), 97-108. https://doi.org/10.5304/jafscd.2014.044.017

Conner, D., Colasanti, K., Ross, R. B., \& Smalley, S. B. (2010). Locally grown foods and farmers markets: Consumer attitudes and behaviors. Sustainability, 2(3), 742-756. https://doi.org/10.3390/su2030742

Detre, J. D., Mark, T. B., \& Clark, B. M. (2010). Understanding why college-educated millennials shop at farmers markets: An analysis of students at Louisiana State University. Journal of Food Distribution Research, 41(3), 14-24. https://doi.org/10.22004/ag.econ.139060

Dodds, R., Holmes, M., Arunsopha, V., Chin, N., Le, T., Maung, S., \& Shum, M. (2014). Consumer choice and farmers’ markets. Journal of Agricultural and Environmental Ethics, 27(3), 397-416. https://doi.org/10.1007/s10806-013-9469-4

${ }^{6}$ https://farm2facts.org/ 
Farmer, J. R., Chancellor, C., Gooding, A., Shubowitz, D., \& Bryant, A. (2011). A tale of four farmers markets: Recreation and leisure as a catalyst for sustainability. Journal of Park and Recreation Administration, 29(3). Retrieved from https://js.sagamorepub.com/ipra/

Farmer, J. R., Chancellor, C., Robinson, J. M., West, S., \& Weddell, M. (2014). Agrileisure. Journal of Leisure Research, 46(3), 313-328. https://doi.org/10.1080/00222216.2014.11950328

Figueroa-Rodríguez, K. A., Álvarez-Ávila, M. del C., Hernández Castillo, F., Schwentesius Rindermann, R., \& FigueroaSandoval, B. (2019). Farmers' market actors, dynamics, and attributes: A bibliometric study. Sustainability, 11 (3), 745. https://doi.org/10.3390/su11030745

Freedman, D. A., Flocke, S., Shon, E.-J., Matlack, K., Trapl, E., Ohri-Vachaspati, P., ... Borawski, E. (2017). Farmers' market use patterns among Supplemental Nutrition Assistance Program recipients with high access to farmers' markets. Journal of Nutrition Education and Behavior, 49(5), 397-404.e1. https://doi.org/10.1016/i.jneb.2017.01.007

Hinrichs, C. C., Gillespie, G. W., \& Feenstra, G. W. (2004). Social learning and innovation at retail farmers' markets. Rural Sociology, 69(1), 31-58. https://doi.org/10.1526/003601104322919892

Kahn, B. E., \& Lehmann, D. R. (1991). Modeling choice among assortments. Journal of Retailing, 67(3), $274-299$. https://doi.org/10.1086/504135

Karakus, M., Milfort, R., MacAllum, K., \& Hongsheng, H. (2014). Nutrition assistance in farmers markets: Understanding the shopping patterns of SNAP participants. Washington, D.C.: USDA Food and Nutrition Service. Retrieved from https://www.fns.usda.gov/snap/nutrition-assistance-farmers-markets-understanding-shopping-patterns-snapparticipants

Karpyn, A., Kim, S. A., DaCosta, R. V., Gasinu, S., \& Law, Y.-M. (2012). Growing the field: Current approaches to data collection at farmers' markets. Journal of Hunger \& Environmental Nutrition, 7(4), 436-448. https://doi.org/10.1080/19320248.2012.732924

Landis, B., Smith, T. E., Lairson, M., Mckay, K., Nelson, H., \& O’Briant, J. (2010). Community-supported agriculture in the Research Triangle Region of North Carolina: Demographics and effects of membership on household food supply and diet. Journal of Hunger \& Environmental Nutrition, 5(1), 70-84. https://doi.org/10.1080/19320240903574403

Low, S. A., Adalja, A., Beaulieu, E., Key, N., Martinez, S., . . Jablonski, B. B. R. (2015). Trends in U.S. local and regional food systems: A report to Congress (Report No. AP-068). Washington, D.C.: USDA Economic Research Service. Retrieved from https://www.ers.usda.gov/publications/pub-details/?pubid $=42807$

Mack, J., \& Tong, D. (2015). Characterizing the spatial and temporal patterns of farmers' market visits. Applied Geography, 63, 43-54. https://doi.org/10.1016/j.apgeog.2015.06.005

McEachern, M. G., Warnaby, G., Carrigan, M., \& Szmigin, I. (2010). Thinking locally, acting locally? Conscious consumers and farmers' markets. Journal of Marketing Management, 26(5-6), 395-412. https://doi.org/10.1080/02672570903512494

McGuirt, J. T., Jilcott Pitts, S. B., Ward, R., Crawford, T. W., Keyserling, T. C., \& Ammerman, A. S. (2014). Examining the influence of price and accessibility on willingness to shop at farmers' markets among low-income eastern North Carolina women. Journal of Nutrition Education and Behavior, 46(1), 26-33. https://doi.org/10.1016/i.jneb.2013.06.001

Meenar, M., Morales, A., \& Bonarek, L. (2017). Regulatory practices of urban agriculture: A connection to planning and policy. Journal of the American Planning Association, 83(4), 389-403. https://doi.org/10.1080/01944363.2017.1369359

Mino, R., Chung, K., \& Montri, D. (2018). A look from the inside: Perspectives on the expansion of food assistance programs at Michigan farmers markets. Agriculture and Human Values, 35(4), 823-835. https://doi.org/10.1007/s10460-018-9877-1

Morales, A. (2000). Peddling policy: Street vending in historical and contemporary context. International Journal of Sociology and Social Policy, 20(3/4), 76-98. https://doi.org/10.1108/01443330010789133

Morales, A. (2009). Public markets as community development tools. Journal of Planning Education and Research, 28(4), 426440. https://doi.org/10.1177/0739456X08329471

Morales, A. (2011). Marketplaces: Prospects for social, economic, and political development. Journal of Planning Literature, 26(1), 3-17. https://doi.org/10.1177/0885412210388040 
Morales, A. (2019). Food systems: (Im)practical interactions. The Pluralist, 14(1), 21-46. https://doi.org/10.5406/pluralist.14.1.0021

Morales, A., Balkin, S., \& Persky, J. (1995). The value of benefits of a public street market: The case of Maxwell Street. Economic Development Quarterly, 9(4), 304-320. https://doi.org/10.1177/089124249500900402

Olson, K. A. (2019). The town that food saved? Investigating the promise of a local food economy in Vermont. Local Environment, 24(1), 18-36. https://doi.org/10.1080/13549839.2018.1545753

Parsons, M., \& Morales, A. (2013). Increasing the healthiness of consumers through farmers markets. Journal of Extension, 51(4). Retrieved from https://www.joe.org/joe/2013august/iw5.php

Printezis, I., \& Grebitus, C. (2018). Marketing channels for local food. Ecological Economics, 152, $161-171$. https://doi.org/10.1016/j.ecolecon.2018.05.021

Quintana, M., \& Morales, A. (2015). Learning from listservs: Collaboration, knowledge exchange, and the formation of distributed leadership for farmers' markets and the food movement. Studies in the Education of Adults, 47(2), $160-175$. https://doi.org/10.1080/02660830.2015.11661682

Rhoades, S. A. (1993). The Herfindahl-Hirschman Index Note. Federal Reserve Bulletin, 79, 188-189. Available by request from https://EconPapers.repec.org/RePEc:fip:fedgrb:y:1993:i:mar:p:188-189:n:v.79no.3

Roubal, A., \& Morales, A. (2016). Chicago marketplaces: Advancing access to healthy food. In J. Dawson \& A. Morales (Eds.), Cities of farmers: Problems, possibilities and processes of producing food in cities (pp. 191-212). Iowa City: University of Iowa Press.

Roubal, A. M., Morales, A., Timberlake, K., \& Martinez-Donate, A. (2016). Examining barriers to implementation of electronic benefit transfer (EBT) in farmers markets: Perspectives from market managers. Journal of Agriculture, Food Systems, and Community Development, 6(3), 141-161. https://doi.org/10.5304/jafscd.2016.063.011

Schmit, T. M., Jablonski, B. B. R., \& Mansury, Y. (2016). Assessing the economic impacts of local food system producers by scale: A case study from New York. Economic Development Quarterly, 30(4), 316-328. https://doi.org/10.1177/0891242416657156

Shumway, R. H., \& Stoffer, D. S. (2011). Time series analysis and its applications: With R examples (3rd ed). New York: Springer.

Stephenson, G., Lev, L., \& Brewer, L. (2008). 'I'm getting desperate': What we know about farmers' markets that fail. Renewable Agriculture and Food Systems, 23(3), 188-199. https://doi.org/10.1017/S1742170507002153

Tan, L. P., \& Cadeaux, J. (2011). Brand and stock-keeping-unit (SKU) assortments, assortment changes and category sales. The International Review of Retail, Distribution and Consumer Research, 21(2), 161-185. https://doi.org/10.1080/09593969.2011.562682

Tey, Y. S., Arsil, P., Brindal, M., Teoh, C. T., \& Lim, H. W. (2017). Motivations underlying consumers' preference for farmers' markets in Klang Valley: A means-end chain approach. Sustainability, 9(11), 1958. https://doi.org/10.3390/su9111958

Thilmany, D., Bond, C. A., \& Bond, J. K. (2008). Going local: Exploring consumer behavior and motivations for direct food purchases. American Journal of Agricultural Economics, 90(5), 1303-1309. https://doi.org/10.1111/j.1467-8276.2008.01221.x

Trivette, S. A., Archambault, S., \& Morales, A. (2015). Money made at the market: Sales at the Williamsburg Farmers Market2002-2014 (URPL Working Paper No. 2015-002). Madison: University of Wisconsin-Madison.

U.S. Department of Agriculture, Agricultural Marketing Service (USDA AMS). (n.d.). Local Food Directories | Agricultural Marketing Service. Retrieved March 10, 2019, from https://www.ams.usda.gov/local-food-directories/farmersmarkets

USDA National Agricultural Statistics Service (USDA NASS). (2016). Census of Agriculture—Local Food Marketing Practices. Retrieved June 12, 2019, from https://www.nass.usda.gov/Publications/AgCensus/2012/Online Resources/Local Food/index.php

Wilson, M., Witzling, L., Shaw, B., \& Morales, A. (2018). Contextualizing farmers' market needs: Assessing the impact of community type on market management. Journal of Food Distribution Research, 49(2), 1-18. https://www.fdrsinc.org/journal/ 
Wittman, H., Beckie, M., \& Hergesheimer, C. (2012). Linking local food systems and the social economy? Future roles for farmers' markets in Alberta and British Columbia. Rural Sociology, 77(1), 36-61. https://doi.org/10.1111/j.1549-0831.2011.00068.x

Witzling, L., Shaw, B., Wilson, M., \& Morales, A. (2019). Promoting farmers' markets: Preferences of farmers' market leaders. Journal of Extension, 57(3), 3FEA4. Retrieved from https://www.joe.org/joe/2019june/a4.php

Zellner, A., \& Theil, H. (1962). Three-stage least squares: Simultaneous estimation of simultaneous equations. Econometrica, 30(1), 54-78. https://doi.org/10.2307/1911287 


\section{Methodological Appendix}

The general model for ARMAX is seen in equation 2:

$$
S A L E S A_{t}=\beta_{0}+\mathrm{BX}_{t}+\omega_{t}
$$

where $S A L E S A_{t}$ represents sales in time period $(t)$, which is predicted by the constant $\left(\beta_{0}\right)$, and a vector of explanatory variables $\left(\mathrm{X}_{t}\right)$ that also change with time. The term $\omega_{t}$ is the residuals component, which we also allow to vary by time. A challenge in the estimation of equation (2) is the potential endogeneity of one or more of the explanatory variables. In this context, it is likely the case that customer counts are both endogenous and predicted by several of the same factors as those that predict sales. 